\title{
Early experience and the development of predatory and intraspecific aggression in mice
}

\author{
JOHN P. WHELTON, JR., and MICHAEL O'BOYLE \\ University of Southern Mississippi, Hattiesburg, Mississippi 39401
}

\begin{abstract}
Three experiments examined the mouse-fighting and cricket-attacking responses of ICR mice reared under various conditions. Groups of mice were raised in isolation, with other mice, or exposed to protected or unprotected crickets. Two aggression testing periods were held when the mice were between 40-45 and 60-65 days of age. Daily aggression tests, consisting of 10-min presentations of a cricket or mouse, were conducted during these periods. Attack latencies were measured on each trial. Analyses of attacks indicated that (1) early experience had little effect on cricket attacks-most mice readily attacked crickets; (2) mice attacked both crickets and other mice faster at 60-65 days of age than at 40-45 days of age; and (3) groupreared mice and female mice were less aggressive towards other mice than were mice raised in isolation or mice raised with crickets.
\end{abstract}

Aggressive behaviors may be modified by early experience. Mice raised in isolation are typically more aggressive toward other mice than are mice raised as a group (e.g., Dimond, 1970; Moyer, 1976; Scott, 1966). Predatory behaviors may also be modified by experience. Prior socialization between predator and potential prey has been found to reduce the predatory behaviors of dogs (Kuo, 1969; but see Cairns \& Werboff, 1967), cats (Kuo, 1930, 1960), and rats (Galef, 1970; Myer, 1969). However, Johnson, Desisto, and Koenig (1972) reported that rats did not become socially attached to, and readily attacked, frogs and cockroaches with which they were cross-reared.

Mice will fight other mice (e.g., Scott, 1966) and attack crickets (Thomas, 1969). Butler (1973) reported cricket-killing and eating in several strains of mice. Most mice tested attacked crickets and most attacks were followed by eating. Lowe and O'Boyle (1976) found that male ICR mice reliably killed and ate crickets. The cricket-killing response of mice would seem to provide a convenient model of predation. It has been suggested that predatory behaviors are functionally distinct from other behaviors typically called aggressive (e.g., intraspecific fighting, see Carthy \& Ebling, 1964; Moyer, 1968; O'Boyle, 1974). If this is the case, it may be expected

Experiment 1 is based on portions of a dissertation submitted by John Whelton to the Psychology Department, University of Southern Mississippi, in partial fulfillment of the requirements for the PhD degree. Portions of this work were presented at the meeting of the Southeastern Psychological Association, New Orleans, March 1976. The authors wish to thank Sammie Butler for his assistance. Supported in part by Grant 1 R03 MH 2636-01 USM from the National Institute of Mental Health. Requests for reprints should be sent to Michael O'Boyle, Box 25, Southern Station, Hattiesburg, Mississippi 39401. that early experience will have differential effects on predatory behaviors and intraspecific fighting. On the other hand, Thomas (1969) compared the predatory and intraspecific fighting behaviors of two strains of mice (C57BL/Crgl and $\left.\mathrm{I}^{\mathrm{s}} / \mathrm{Bi} / \mathrm{Crgl}\right)$ and noted that the $\mathrm{I}^{\mathrm{s}}$ mice were more efficient predators and were more aggressive toward other mice in the group cages. The present experiments examined the effects of different early environments on the mousefighting and cricket-attacking responses of ICR mice.

\section{EXPERIMENT 1}

Experiment 1 compared the aggressive responses of three groups of mice; mice raised in isolation, with other mice, or with crickets.

\section{Method}

Subjects. Sixty male albino mice [Dub (ICR), Flow Laboratories], 24 days of age at the start of the study, were used. Thirty of these mice served as targets for aggression tests and 30 as subjects. Domestic crickets (Acheta domesticus), obtained from a local bait shop, were used as prey targets.

Procedure. The 30 subject mice were randomly assigned to the following groups: (1) Ten mice were raised in isolation, being housed individually in translucent plastic cages $(28.2 \times 15.2$ $\times 8.9 \mathrm{~cm}$ ) with plastic tops. The tops had holes and were lined with aluminum screening. (2) Ten mice were reared with crickets. The mice were individually housed with a cricket in cages identical to those described for the first group. The crickets were checked daily, and those that had been killed or mutilated were replaced. (3) Ten mice were raised as a group, in a cage approximately 10 times the size of the individual cages used for the other two groups $(65 \times 65 \times 8.9 \mathrm{~cm})$.

All mice remained under these conditions throughout the study, aside from two aggression testing periods, which took place when the mice were between 40 and 45 and between 60 and 65 days of age. Food, water, and cricket feed were available throughout the study.

Aggression tests. At age 39 days, all mice were removed from their home cages and placed in individual plastic cages $(28.2 \times$ 
$15.2 \times 8.9 \mathrm{~cm}$ ) for a $24-\mathrm{h}$ adaptation period. Daily aggression tests began the next day, when the mice were 40 days old. Each test consisted of a 10 -min presentation of a cricket or a mouse. The target (cricket or mouse) was alternated each day. Half of the mice in each group were exposed to a mouse on Day 40, a cricket on Day 41, a mouse on Day 42, and so on. The reverse presenta. tion order was employed for the remaining mice. Thus, each mouse was exposed to three mice and three crickets. Mouse and cricket targets were rotated so that no subject mouse was ever exposed to the same target more than once.

This procedure was repeated when the mice were between 59 and 65 days of age. The subject mice were returned to their home cages and experimental rearing conditions between aggression testing periods (i.e., from age 46 days to age 58 days).

Attack latencies were measured on each trial. An attack was defined as pouncing on, striking with the teeth, or tearing with the forepaws (Butler, 1973; Scott, 1966). If no attacks occurred, a time of $600 \mathrm{sec}$ was recorded for the trial. The reliability of this measure was checked periodically by having a second observer record attack latencies independently.

\section{Results}

The attack latency data during the formal aggression testing periods are summarized in Table 1.

An analysis of variance of the attack latency data showed that significant differences existed between the three groups $[F(2,27)=11.49, \mathrm{p}<.001]$. Since the Rearing Condition by Target (cricket vs. mouse) interaction was also significant $[\mathrm{F}(2,27)=9.63$, $\mathrm{p}<.001]$ comparisons were made using the NewmanKeuls test.

It was found that mice raised with crickets and mice raised in isolation attacked other mice with significantly shorter latencies than did group-reared mice $(p<.01)$. Type of rearing had no effect upon latency to attack crickets in that no significant differences between any of the three groups were obtained (p > .05). All groups attacked crickets with significantly shorter latencies than they attacked mice $(p<.05)$, and all groups attacked both crickets and mice with significantly shorter latencies during the second testing period beginning at age 60 days $[\mathrm{F}(2,27)=17.61, \mathrm{p}<.001]$.

The attack latency data were also analyzed over individual testing days. This was done to gauge any training effects that might have accrued to the mice that had been exposed to (and typically attacked) crickets prior to the formal aggression tests. In addition, the use of grouped measures over days in the prior analysis may have obscured transient differences between groups. An extension of Wilcoxon's rank-sum test (Wilcoxon \& Wilcox, 1964) was used to compare the latencies of all possible pairs of groups on each trial. All of the latencies were ranked for each trial, and the rank sum for each of the three groups was computed. Significant differences in rank sums are given in Table 2, which also gives the median attack latency for each group on each day and the proportion of mice attacking crickets or mice on each test day.

Mouse targets. A series of rank-sum tests compariing individual mouse attack latencies across groups showed that (1) the cricket-reared and isolated groups did not differ significantly with respect to attack latency on any test trial; and (2) group-reared mice were consistently less aggressive towards the mouse targets than were mice in cricket-reared or isolated groups. The rank-sum tests indicated that the attack latencies of the group-reared mice were significantly longer than those of the cricket-reared and isolated mice on four of the six mouse target trials. In addition, the proportion of group-reared mice attacking mice was always smaller than the proportions of the other groups (see Table 2).

Cricket targets. A series of rank-sum tests comparing individual cricket attack latencies across groups indicated that the group-reared mice attacked crickets with significantly longer latencies that did mice in both other groups on the first cricket test, although the groups' cricket attack latencies did not differ significantly on any other test trial. The proportions of mice attacking crickets on any test day were virtually the same for all groups. This analysis indicates that early experience with crickets had little effect on predatory behavior. For example, the cricket-reared and isolated groups, which differed greatly in their experience with crickets prior to formal aggression testing, did not differ significantly with respect to cricket attack behavior during the formal aggression tests. It was noted that mice raised with crickets readily attacked and ate them prior to the formal aggression testing periods. Crickets typically had to be replaced every day.

Interobserver reliability. A Pearson productmoment correlation was computed between the experimenter and an observer who periodically and independently recorded attack latencies. The Pearson r was .99 , a value consistent with Butler's (1973)

Table 1

Experiment 1

Attack Latencies During Formal Testing Periods (sec)

\begin{tabular}{|c|c|c|c|c|}
\hline \multirow[b]{3}{*}{ Group } & \multicolumn{2}{|c|}{ Latency to Attack Mice } & \multicolumn{2}{|c|}{ Latency to Attack Crickets } \\
\hline & 40-45 Days & 60-65 Days & 40-45 Days & 60-65 Days \\
\hline & Mean SD & Mean SD & Mean SD & Mean SD \\
\hline $\begin{array}{l}\text { Cricket Reared } \\
\text { Isolates } \\
\text { Group Reared }\end{array}$ & $\begin{array}{l}204.6 \pm 243.8 \\
261.4 \pm 255.2 \\
521.1 \pm 161.7\end{array}$ & $\begin{array}{r}120.6 \pm 220.8 \\
71.3 \pm 164.0 \\
427.2 \pm 255.7\end{array}$ & $\begin{array}{r}80.6 \pm 114.0 \\
66.1 \pm 86.3 \\
188.1 \pm 209.3\end{array}$ & $\begin{array}{l}44.1 \pm 113.5 \\
58.4 \pm 121.1 \\
65.0 \pm 155.0\end{array}$ \\
\hline
\end{tabular}


Table 2

Experiment 1

Median Trial Times (sec) and Proportion of Each Group Attacking Over Test Days

\begin{tabular}{|c|c|c|c|c|c|c|c|c|}
\hline \multirow[b]{3}{*}{ Trial } & \multicolumn{4}{|c|}{ Cricket Trials } & \multicolumn{4}{|c|}{ Mouse Trials } \\
\hline & \multicolumn{2}{|c|}{ 40-45 Days } & \multicolumn{2}{|c|}{ 60-65 Days } & \multicolumn{2}{|c|}{ 40-45 Days } & \multicolumn{2}{|c|}{ 60-65 Days } \\
\hline & MT & $\mathbf{P}$ & MT & $\mathbf{P}$ & MT & $\mathbf{P}$ & MT & $\mathbf{P}$ \\
\hline \multicolumn{9}{|c|}{ Cricket Reared } \\
\hline 1 & 19.5 & $10 / 10$ & 15 & $10 / 10$ & 196.5 & $7 / 10$ & 2.5 & $8 / 10$ \\
\hline 2 & 60 & $10 / 10$ & 11.5 & $10 / 10$ & 67.5 & $7 / 10$ & 10 & $8 / 10$ \\
\hline 3 & 41.5 & $10 / 10$ & 7.5 & $9 / 10$ & 43.5 & $9 / 10$ & 4.5 & $10 / 10$ \\
\hline \multicolumn{9}{|c|}{ Isolates } \\
\hline 1 & 39 & $10 / 10$ & 21 & $9 / 10$ & 412 & $6 / 10$ & 6 & $10 / 10$ \\
\hline 2 & 60.5 & $10 / 10$ & 13.5 & $10 / 10$ & 255.5 & $7 / 10$ & 4.5 & $9 / 10$ \\
\hline 3 & 36 & $10 / 10$ & 22 & $10 / 10$ & 20.5 & $8 / 10$ & 3.5 & $9 / 10$ \\
\hline \multicolumn{9}{|c|}{ Group Reared } \\
\hline 1 & $134^{*}$ & $7 / 10$ & 13 & $9 / 10$ & $600^{*}$ & $1 / 10$ & $600 \dagger$ & $1 / 10$ \\
\hline 2 & 128 & $9 / 10$ & 10 & $10 / 10$ & 600 & $4 / 10$ & $600 * *$ & $4 / 10$ \\
\hline 3 & 49.5 & $10 / 10$ & 7.5 & $10 / 10$ & $600 \dagger$ & $2 / 10$ & $344.5^{\dagger}$ & $6 / 10$ \\
\hline
\end{tabular}

Note-MT $=$ Median Trial Times; $P=$ Proportion. $\quad$ *Different from cricket-reared group $(p<.05) \quad{ }^{*}$ Different from isolated group $(p<.05) \quad$ fDifferent from isolated and cricket-reared group $(p<.05)$

reliability data and one which indicates that the interand intraspecific attacks were conspicuous and easily observed.

\section{EXPERIMENT 2}

Experiment 1 found that early exposure to crickets had no significant impact on cricket attacks by mice during later aggression tests. All mice were 24 days old at the start of the study, and all mice exposed to crickets attacked them repeatedly before the formal aggression tests. It may be that earlier exposure to crickets would modify the subsequent aggressive behavior of mice. In Experiment 2, we tested this notion and also examined the emergence of aggressive responses towards crickets among young mice.

\section{Method}

Subjects. Two litters of ICR mice born in the school laboratory served as subjects. Target mice were young male ICR mice about 43 days old at the start of the study. Domestic crickets (Acheta domesticus) served as prey targets. Food and water were available throughout the study.

Apparatus. Mice in each litter were raised with their mothers in translucent plastic cages $(28.2 \times 15.2 \times 8.9 \mathrm{~cm})$ with stainless steel tops. Aggression tests took place in similar plastic cages.

Procedure. In the birth-exposure group, mice in one litter (four males, four females) were individually exposed to crickets for $1 \mathrm{~h}$ per day from age 1 day to age 20 days. A test consisted of removing a mouse from the litter, placing it in an individual plastic cage with a cricket, and noting if an attack occurred. After each test, the mouse was returned to the litter.

In the 19-day exposure group, mice in another litter (seven males, three females) were housed with their mother. They received individual 1-h cricket tests (as described for the birth exposure group) at 19 and 20 days of age.

At 21 days of age, mice in both groups were weaned and housed individually in plastic cages. From this point on, the procedure followed for all mice was identical to the procedure employed for the cricket-reared groups in Experiment 1. All mice were housed individually with a cricket. The mouse-cricket pairs were checked daily, and those crickets that had been killed or mutilated were replaced. When the mice were 39 days old, they were moved to new individual cages, where daily aggression tests with mouse and cricket targets were held. These tests were conducted over two periods, one when the mice were between 40 and 45 days of age, the other when they were between 60 and 65 days of age. Between testing periods, all mice were returned to their individual cages and housed with crickets.

\section{Results}

All mice consistently attacked crickets prior to the formal aggression tests, which began at age 40 days. The age at first attack ranged from 18 to 26 days. The emergence of the cricket attack response is outlined in Table 3, which gives the proportion of mice in each group attacking crickets each day. There were no significant differences between groups on any day (e.g., Day 20, Fisher exact test $\mathrm{p}>.05$ ). The cricket attack response typically emerged at about the time the mice were weaned, regardless of early experience.

The attack latencies of the mice towards mouse and cricket targets were measured during the formal aggression tests. These data are summarized in Table 4. An analysis of variance of the attack latencies indicated that early exposure to crickets (i.e., from birth vs. at 19 days of age) had no significant effect on attack latencies $[F(1,14)<1]$. The sex of the subject mouse was a highly significant variable $[F(1,14)=27.12, p<.005]$. Since the Sex by Experience interaction was not significant $[F(1,14)<1$, it may be concluded that female mice were less aggressive than males.

The analysis of variance also indicated that both the target [mouse or cricket; $F(1,14)=50.24, p<$ $.001]$ and age at testing [40-45 days vs. 60-65 days; $\mathrm{F}(1,14)=5.34, \mathrm{p}<.01]$ variables significantly 
Table 3

Experiment 2

Mean Attack Latencies During Formal Testing Periods (sec)

\begin{tabular}{|c|c|c|c|c|c|}
\hline \multirow{3}{*}{$\begin{array}{l}\text { Age at First } \\
\text { Exposure }\end{array}$} & \multirow[b]{3}{*}{ Sex } & \multicolumn{2}{|c|}{ Latency to Attack Mice } & \multicolumn{2}{|c|}{ Latency to Attack Crickets } \\
\hline & & 40-45 Days & 60-65 Days & 40-45 Days & 60-65 Days \\
\hline & & Mean & Mean & Mean & Mean \\
\hline Birth & $\begin{array}{l}\text { Male }(n=4) \\
\text { Female }(n=4)\end{array}$ & $\begin{array}{l}373.5 \pm 134.7 \\
600.0 \pm 0\end{array}$ & $\begin{array}{rr}91.6 \pm & 74.2 \\
596.7 \pm & 5.5\end{array}$ & $\begin{array}{l}131.1 \pm 80.6 \\
178.1 \pm 67.5\end{array}$ & 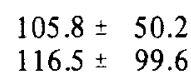 \\
\hline 19 Days & $\begin{array}{l}\text { Male }(n=7) \\
\text { Female }(n=3)\end{array}$ & $\begin{array}{c}246.5 \pm 194.6 \\
600.0 \pm 0\end{array}$ & $\begin{array}{l}202.7 \pm 219.2 \\
600.0 \pm 0\end{array}$ & $\begin{array}{l}182.7 \pm 127.8 \\
181.1 \pm 91.2\end{array}$ & $\begin{array}{r}134.5 \pm 92.0 \\
136.3 \pm 118.8\end{array}$ \\
\hline
\end{tabular}

Table 4

Experiment 2

Proportion of Each Group Attacking Crickets Over Days

\begin{tabular}{|c|c|c|c|c|c|c|c|c|c|c|c|c|c|c|c|c|}
\hline \multirow{2}{*}{$\begin{array}{c}\text { Age at First } \\
\text { Exposure }\end{array}$} & \multicolumn{16}{|c|}{ Age (days) } \\
\hline & $1-17$ & 18 & 19 & 20 & 21 & 22 & 23 & 24 & 25 & $26-27$ & $28-38$ & 39 & $40-45$ & $46-58$ & 59 & $60-65$ \\
\hline $\begin{array}{l}\text { Birth } \\
19 \text { Days }\end{array}$ & $0 / 8$ & $1 / 8$ & $\begin{array}{l}2 / 8 \\
0 / 10\end{array}$ & $\begin{array}{l}3 / 8 \\
0 / 10\end{array}$ & $\begin{array}{l}5 / 8 \\
2 / 10\end{array}$ & $\begin{array}{l}5 / 8 \\
8 / 10\end{array}$ & $\begin{array}{l}7 / 8 \\
9 / 10\end{array}$ & $\begin{array}{l}7 / 8 \\
8 / 10\end{array}$ & $\begin{array}{l}7 / 8 \\
7 / 10\end{array}$ & $\begin{array}{l}8 / 8 \\
9 / 10\end{array}$ & $\begin{array}{c}8 / 8 \\
10 / 10\end{array}$ & & $\begin{array}{l}4 / 4^{*} \\
5 / 5^{*}\end{array}$ & $\begin{array}{c}8 / 8 \\
10 / 10\end{array}$ & & $\begin{array}{l}4 / 4^{*} \\
5 / 5^{*}\end{array}$ \\
\hline
\end{tabular}

*Half of each group was tested with a cricket on a given test day.

affected attack latencies. The Sex by Target interaction was also significant $[F(1,14)=22.16, p<$ $.005]$.

This analysis indicated that mice generally attacked both mice and crickets faster at 60-65 days of age than at 40-45 days of age. Newman-Keuls comparisons showed that male mice were more aggressive towards mouse targets than were female mice $(\mathrm{p}<$ $.05)$. The female subjects often did not attack target mice during the 10-min trials, yielding latency scores of $600 \mathrm{sec}$ (see Table 2). In contrast, all mice readily attacked crickets during the formal aggression tests.

\section{EXPERIMENT 3}

The results of the first two experiments indicated that ICR mice will typically attack crickets even when exposed to them before weaning. All mice raised with crickets repeatedly attacked them prior to the formal aggression tests beginning at age 40 days. However, one would not expect a social attachment to develop towards an insect that had been killed. In other studies dealing with interspecific attachments (e.g., Johnson et al., 1972; Kuo, 1960), different species have been exposed to one another but aggressive responses were restrained or prevented [e.g., Johnson et al. (1972) exposed rats to protected cockroaches]. The present experiment compared the aggressive responses of mice exposed to protected crickets with those of mice housed in isolation.

\section{Method}

Subjects. Two litters $(n=14)$ of ICR mice born in the school laboratory served as subjects. They were housed with their mothers in translucent plastic cages $(28.2 \times 15.2 \times 8.9 \mathrm{~cm})$ with stainless steel tops. The mice were weaned at 21 days, and transferred to individual cages, where they remained for the duration of the study.

Domestic crickets (Acheta domesticus) were used as prey targets. Adult male ICR mice also served as targets.

Apparatus. All mice were tested in their home cage (Hoeltge Model LC-75/A), which had steel sides and a grid floor and front $(25 \times 18 \times 18 \mathrm{~cm}$ high). The crickets were protected by being placed in clear plastic pill bottles $(6.0 \mathrm{~cm}$ high $\times 4.8 \mathrm{~cm}$ diameter) which had white plastic screw tops. Small air holes were drilled in each bottle.

Procedure. The 14 mice were randomly separated into two groups, with the provision that the distribution of sexes in each group be as even as possible.

Seven mice (three males, four females) served in the protectedcricket group. A plastic bottle containing a live cricket was placed in the cage of each mouse upon being weaned and transferred to individual cages. Bottles were checked daily, and dead crickets were replaced as needed. The bottles were removed when formal aggression tests began (age $\mathbf{4 0}$ days).

Seven mice (two males, five females), housed individually with an empty plastic bottle, served as a control group. The bottle was removed when formal aggression tests began.

When the mice in both groups were 40 days old, the bottles were removed from the cages and daily aggression trials began. Daily aggression tests were held over two periods, one when the mice were between 40 and 45 days of age, the other when they were between 60 and 65 days of age. The sequence and order of testing were identical to Experiments 1 and 2. Since the tests took place in cages with a grid floor, the crickets were restrained by being held with wooden clip-type clothespins. Attack latencies or failures to attack during a 10-min trial were measured on each test.

\section{Results}

Table 5 gives the median attack latencies for each group on each test trial, and the proportions of mice attacking mouse or cricket targets over trials (each subject mouse was exposed to six crickets and six mice in a counterbalanced order, as in Experiment 1). Mann-Whitney $U$ tests comparing the individual 
Table 5

Experiment 3

Median Trial Times (sec), and Proportion of Each Group Attacking Over Test Days

\begin{tabular}{|c|c|c|c|c|c|c|c|c|}
\hline \multirow[b]{3}{*}{ Trial } & \multicolumn{4}{|c|}{ Cricket Trials } & \multicolumn{4}{|c|}{ Mouse Trials } \\
\hline & \multicolumn{2}{|c|}{ 40-45 Days } & \multicolumn{2}{|c|}{ 60-65 Days } & \multicolumn{2}{|c|}{ 40-45 Days } & \multicolumn{2}{|c|}{ 60-65 Days } \\
\hline & MT & $\mathbf{P}$ & MT & $\mathbf{P}$ & MT & $\mathbf{P}$ & MT & $\mathbf{P}$ \\
\hline \multicolumn{9}{|c|}{ Protected Cricket } \\
\hline $\begin{array}{l}1 \\
2 \\
3\end{array}$ & $\begin{array}{r}330 \\
72 \\
71\end{array}$ & $\begin{array}{l}6 / 7 \\
7 / 7 \\
6 / 7\end{array}$ & $\begin{array}{l}93 \\
88 \\
52\end{array}$ & $\begin{array}{l}6 / 7 \\
6 / 7 \\
6 / 7\end{array}$ & $\begin{array}{r}340 \\
90 \\
95\end{array}$ & $\begin{array}{l}4 / 7 \\
6 / 7 \\
6 / 7\end{array}$ & $\begin{array}{l}190 \\
243 \\
320\end{array}$ & $\begin{array}{l}6 / 7 \\
6 / 7 \\
5 / 7\end{array}$ \\
\hline \multicolumn{9}{|c|}{ Isolates } \\
\hline $\begin{array}{l}1 \\
2 \\
3\end{array}$ & $\begin{array}{r}126 \\
69 \\
69\end{array}$ & $\begin{array}{l}7 / 7 \\
6 / 7 \\
7 / 7\end{array}$ & $\begin{array}{r}160 \\
96 \\
31\end{array}$ & $\begin{array}{l}6 / 7 \\
6 / 7 \\
7 / 7\end{array}$ & $\begin{array}{r}129 \\
74 \\
600\end{array}$ & $\begin{array}{l}5 / 7 \\
7 / 7 \\
3 / 7\end{array}$ & $\begin{array}{r}90 \\
41 \\
600\end{array}$ & $\begin{array}{l}5 / 7 \\
4 / 7 \\
2 / 7\end{array}$ \\
\hline
\end{tabular}

Note-MT $=$ Median Trial Times; $P=$ Proportion.

attack latencies of the two groups on each trial showed no significant differences between groups. Exposure to protected crickets did not significantly affect the aggressive behavior of the mice. Most mice attacked crickets quickly and consistently.

Although we were primarily interested in cricket attacks, intraspecific attacks were also examined. The data revealed no significant differences between groups with regard to attack behavior. Sex differences were assessed by a series of Mann-Whitney $U$ tests, which compared the attack latencies of male and female mice on each test trial (regardless of experimental group). These comparisons showed that (1) no significant differences existed with respect to cricket attacks-most male and female mice readily attacked crickets-and (2) females attacked target mice with significantly $\left(\mathrm{U} \leqslant 7, \mathrm{n}_{1}=5, \mathrm{n}_{2}=9\right.$, $p<.05$ ) longer latencies than did mice on the final three mouse target trials (at age 60-65 days). Significant differences were found on no other trial.

\section{GENERAL DISCUSSION}

The results indicate that predatory and intraspecific aggression in mice is affected differentially by prior experience. The finding that group-reared mice were less aggressive toward mice than were mice raised in isolation or with crickets is in agreement with prior research (e.g., Moyer, 1976). The general decrease in intraspecific attack latencies with age is also consistent with prior work (King, 1957, but see Morgret, 1973).

With regard to predatory aggression, the finding that mice are more aggressive toward crickets at 60 vs. 40 days is consistent with previous research (Boice \& Schmeck, 1968; Butler, 1973; Thomas, 1969). Butler (1973) concluded that cricket-killing is rapidly learned in adult mice of a wide variety of genotypes. This agrees with results obtained with many other mammals (Polsky, 1975). It appears that predatory attack latencies in mammals tend to decrease with age. Predators appear to learn how to attack and kill more quickly with practice and tend to show a decrease in other time-consuming behaviors such as exploration and manipulation (Polsky, 1975).

The finding that early experience had little impact on cricket attacks is consistent with the idea that predatory aggression and intraspecific fighting are functionally distinct. Informal observations made during aggression tests suggested that cricket attacks were different in form from the fighting behaviors seen between mice. Fights between mice were often accompanied by display behaviors (e.g., tail rattling, squealing) typically not seen when mice attacked crickets. It should be noted that positive relationships between predatory aggression and intraspecific fighting have been found in rats (Barr, Gibbons, \& Moyer, 1975) and in mice (Thomas, 1969).

The main point of the present study is that early experience had little effect on predatory behavior in mice. This agrees with the results of Johnson et al. (1972), who reported that rats did not form social attachments to frogs or cockroaches with which they were cross-reared. In the present study, all mice raised with crickets eventually attacked them, even when the mice were exposed to crickets, protected or not, from birth. In those groups exposed to crickets before weaning, attacks appeared when the mice were from 18 to 26 days of age, regardless of the early experience or sex of the mouse. All mice attacked crickets during the formal aggression tests. Since there is much evidence for the formation of attachments between some species (Cairns \& Werboff, 1967; Galef, 1970; Kuo, 1930, 1960; Myer, 1969), it may be that crickets are too alien to alow the formation of attachments with mice (Johnson et al., 1972). A continuum of similarity may exist along which social attachments are made-the more dissimilar a cagemate, the less likely an attachment. There is other evidence consistent with this idea. Bandler and Moyer (1970) examined predatory aggression in rats and noted that "frogs and turtles elicit attack more frequently than chicks which elicit attack more frequently than mice"' (p. 181). Although other factors undoubtedly played a role in determining attacks, these targets (mouse, chicken, turtle, frog) seem to form a continuum of similarity to rats.

\section{REFERENCES}

Bandler, R., \& MoYer, K. E. Animals spontaneously attacked by rats. Communications in Behavioral Biology, 1970, 5, 177-182.

Barr, G. A., Gibbons, J. L., \& Moyer, K. E. The relationship between mousekilling and intraspecific fighting in the albino rat. Behavioral Biology, 1975, 14, 201-208. 
Boice, R., \& Schmeck, R. R. Predatory behaviors of grasshopper mice (Onychomys leuchogaster). American Zoologist, 1968, 8, 751. (Abstract)

Butler, K. Predatory behavior in laboratory mice: Strain and sex comparisons. Journal of Comparative and Physiological Psychology, 1973, 85, 243-249.

Cairns, R. B., \& WerbofF, J. Behavioral development in the dog: An interspecific analysis. Science, 1967, 158, 1070-1072.

CARTHY, J. D., \& Ebling, F. J. The natural history of aggression. New York: Academic Press, 1964.

Dimond, S. J. The social behavior of animals. New York: Harper \& Row, 1970.

Galef. B. G. Aggression and timidity: Responses to novelty in feral Norway rats. Journal of Comparative and Physiological Psychology, 1970, 70, 370-381.

Johnson, R. N., Desisto, N. J., \& Koenig, A. B. Social and developmental experience and interspecific aggression in rats. Journal of Comparative and Physiological Psychology, 1972. 79. 237-242.

KING. J. A. Relationships between early social experience and adult aggressive behavior in inbred mice. Joumal of Genetic Psychology, 1957, 90, 151-166.

Kuo, Z. Y. The genesis of the cat's response to the rat. Journal of Comparative Psychology, 1930, 11, 1-35.

Kuo, Z. Y. Studies on the basic factors in animal fighting: VII. Interspecies coexistence in mammals. Joumal of Genetic Psychology, 1960, 97, 211-225.

Lowe, W. C., \& O'Boyle, M. Suppression of cricket killing and eating in laboratory mice following lithium chloride injections. Physiology \& Behavior, 1976, 17. 427-430.

MoRgRET, M. K. The long-term development of fighting in mice: Implications for future research. Developmental Psychobiology, 1973, 6, 503-509.

MOYER, K. E. Kinds of aggression and their physiological basis. Communications in Behavioral Biology, 1968, 2, 65-87.

MoYer, K. E. The psychobiology of aggression. New York: Harper \& Row, 1976.

MYER, J. S. Early experience and the development of mouse-killing by rats. Journal of Comparative and Physiological Psychology, 1969, 67, 46-49.

O'Boyle, M. Rats and mice together: The predatory nature of the rat's mouse-killing response. Psychological Bulletin, 1974. 81, 261-269.

Polsky, R. H. Developmental factors in mammalian predation. Behavioral Biology, 1975, 15, 353-382.

ScotT, J. P. Agonistic behavior of mice and rats: A review. American Zoologist, 1966, 6, 683-701.

Tномаs, K. Predatory behavior in two strains of laboratory mice. Psychonomic Science, 1969, 15, 13-14.

WILcoxon, F., \& Wilcox, R. Some rapid approximate statistical procedures. Pearl River, N.Y: Lederle Laboratories. 1964.

Received for publication February 10, 1977; revision accepted April 18, 1977.) 